\title{
The Effect of Lipopolysaccharide Subunit Vaccine of Brucella abortus on Montanide ISA 70 Adjuvant on Sheep
}

\author{
Faizatul Khusnia ${ }^{1}$, Suwarno ${ }^{1 *}$, and Muhammad Yunus ${ }^{2}$ \\ ${ }^{1}$ Department of Veterinary Microbiology, Faculty of Veterinary Medicine, Universitas Airlangga, Surabaya-60115, Indonesia \\ ${ }^{2}$ Department of Veterinary Parasitology, Faculty of Veterinary Medicine, Universitas Airlangga, Surabaya-60115, Indonesia \\ *Corresponding Author: Suwarno, Department of Veterinary Microbiology, Faculty of Veterinary Medicine, Universitas Airlangga, Campus C UNAIR J1 Dr. Ir. H. \\ Soekarno, Surabaya-60115, East Java, Indonesia; Email: suwarno@fkh.unair.ac.id; (DORCiD: 0000-0002-8592-2877
}

\begin{abstract}
Brucellosis is one of the most important zoonotic diseases in the entire world. This disease results in serious economic loss and public health problems. The disease is caused by gram-negative bacteria of the genus Brucella. There is a need to perform control programs, such as conducting a vaccination program on livestock. One of the vaccine components that can be used is $B$. abortus lipopolysaccharide. The present study aimed to find out the effect of $B$. abortus lipopolysaccharide subunit vaccine in adjuvant Montanide ISA 70 against antibody titer and interferon-gamma (IFN- $\gamma$ ) level by administrating different doses and different post-vaccination sampling times. $B$. abortus lipopolysaccharide was used in the current study as an antigen and Montanide ISA 70 as an adjuvant. The samples were divided into three groups, each containing six sheep. In the control group (P0), the samples received no treatment. In the first treatment group (P1), the samples were subjected to the injection of $B$. abortus lipopolysaccharide subunit in Montanide ISA 70 adjuvant of $50 \mathrm{mg} / \mathrm{ml}$. Regarding the second treatment group (P2), the samples had an injection of $B$. abortus lipopolysaccharide subunit vaccine in $100 \mathrm{mg} / \mathrm{ml}$. The results showed that the administration of $B$. abortus lipopolysaccharide subunit vaccine in the Montanide ISA 70 adjuvant could influence the formation of antibodies and IFN- $\gamma$ secretion on sheep. The administration of a dose of $100 \mu \mathrm{g} / \mathrm{ml}$ indicated a greater antibody titer, compared to the dose of $50 \mu \mathrm{g} / \mathrm{ml}$. The administration of the vaccine at a dose of $50 \mu \mathrm{g} / \mathrm{ml}$ revealed a greater IFN- $\gamma$ level value in comparison with the dose of $100 \mu \mathrm{g} / \mathrm{ml}$. The result of the study on IFN- $\gamma$ level indicated the control group had a greater IFN- $\gamma$ level rather than the treatment group. In Conclusion, The administration of $B$. abortus lipopolysaccharide subunit vaccine in Montanide ISA 70 adjuvant could influence the formation of IFN- $\gamma$ antibody and secretion on sheep.
\end{abstract}

Keywords: B. abortus, Lipopolysaccharide, Montanide ISA 70 Adjuvant, Vaccine

\section{INTRODUCTION}

Brucellosis is known as one of the most significant zoonotic diseases in the entire world since it leads to critical economic and public health problems. Brucellosis which is caused by gram-negative bacteria of the genus Brucella can cause chronic infection both in animals and humans (Xavier et al., 2014). Brucellosis in Indonesia is considered an infectious reproductive disease in livestock. Animals infected with Brucella may experience abortion, retained placenta, orchitis, epididymitis which may excrete germs into the uterus and milk. The economic loss caused by this disease reaches 138.5 billion rupiah per year due to miscarriage rates, infertility, premature death, weak calves, and decreased milk production (Sari et al., 2014).

Although Brucellosis has no effective treatment, vaccination of young cows can be an efficient way to control the disease. The three most common vaccines include the attenuated strain 19 vaccines (S19), the adjuvant vaccine 45/20, and the RB51 vaccine (Davis and Elzer, 2002). In Indonesia, the government approved the B. abortus RB51 vaccine to control brucellosis in cows. Nowadays, the RB51 vaccine is used instead of the S19 vaccine, since it may lead to some problems, including latent infection and prolonged antibodies. These issues can interfere with the serological diagnosis of Brucellosis. The protection caused by the RB51 vaccine is the same as the S19 vaccine leading to infection since it is an active vaccine. Therefore, there is an urgent need to develop an effective and safe vaccine to control the disease.

The lipopolysaccharide (LPS) subunit is a fragment used in developing the B. abortus vaccine. Lipopolysaccharide is the largest surface antigen found in gram-negative bacteria. Therefore it is the basis for the serological classification of various bacterial species and can be useful for the diagnosis of the disease. Moreover, lipopolysaccharides not only play an important role in stabilizing the outer membrane and the biological activity of the most outer membrane protein but also function as receptors for various bacteriophages (Ratnasari et al., 2018). Gram-negative bacterial lipopolysaccharide is the potential antigen that can directly induce the humoral-specific immune response, namely B lymphocyte cells so that they stimulate antibody formation more quickly. An antigen is a substance that can be recognized and bound 
properly by the immune system. The part of the antigen that binds directly to the molecular receptor is known as the antigen determinant or an epitope (Rantam, 2003).

The adjuvant selection also greatly influences the immune response caused during the vaccine. One of the adjuvants that can be used is Montanide ISA 70. Montanide ISA 70 Adjuvant is a water-in-oil adjuvant consisted of oil and a very fine emulgator from the mannide monooleate group. The employed formulation for Montanide induces a long-term and strong immunity, which makes it more stable and easier for injection, compared with the traditional oil emulsion. Furthermore, Montanide has a high immunopotentiation and low side effects (Tehrani et al., 2014) which are the significant factors in the preparation of effective and safe vaccines to manage the disease in livestock. The immunization of animals with a high-quality vaccine is the main control suggestion for different animal diseases. There are some national reports showing that vaccine administration could successfully control and eradicate the disease. The use of Montanide ISA 70 is an alternative choice (Tehrani et al., 2014). This study was aimed to determine the effect of the lipopolysaccharide subunit vaccine in Montanide ISA 70 adjuvant to the antibody titers and interferon-gamma (IFN$\gamma$ ) level of the sheep.

\section{MATERIALS AND METHODS}

\section{Ethical approval}

All process of the present experiment was conducted in Department of Microbiology, Faculty of Veterinary Medicine, Universitas Airlangga, Indonesia and the process was ethically approved by the committee of Universitas Airlangga in terms of animal welfare and ethics.

The present study was an experimental laboratory study in which the effects of adjuvant Montanide ISA 70 and LPS of B. abortus were investigated. Montanide ISA 70 Adjuvant could affect the efficiency of B. abortus LPS as an antigen. The current study was conducted at a sheep farm owned by PT. Agro Great Indoberkah Probolinggo, and at the Virology Laboratory Department of Microbiology, Faculty of Veterinary Medicine, Universitas Airlangga, Surabaya, Indonesia.

The samples in the current study were divided into three treatment groups, namely treatment group (P1), treatment group (P2), and finally the control group (P0). Before starting the treatment, the sheep were divided and put randomly into different cages, each containing six male sheep approved by the veterinary assistant for healthy status before the study. The P0 was the control group that received no treatment entailed six sheep aged two years. P1 referred to the group involved six sheep aged two years treated by giving $B$. abortus LPS injection in Montanide ISA 70 adjuvant at a dose of $50 \mu \mathrm{g} / \mathrm{ml}$ subcutaneously. Finally, P2 was for the group with six sheep aged two years treated by giving $B$. abortus LPS injection in Montanide ISA 70 adjuvant at a dose of $100 \mu \mathrm{g} / \mathrm{ml}$ subcutaneously.

\section{Subunit vaccine formulation}

In the present study, the LPS B. abortus subunit vaccine was administered in the Montanide ISA 70 adjuvant with the dosages of $50 \mu \mathrm{g} / \mathrm{ml}$ and $100 \mu \mathrm{g} / \mathrm{ml}$. The vaccine was made by adding Montanide ISA 70 adjuvant into LPS $B$. abortus with a proportion of 3:7 meaning that each $\mathrm{ml}$ of the subunit vaccine contained $0.3 \mathrm{ml}$ of LPS Brucella abortus and $0.7 \mathrm{ml}$ of Montanide ISA 70 adjuvant (Tehrani et al., 2014).

\section{Raising experimental animals}

The samples of 18 male sheep (Ovis aries) used in this study were divided into three treatment groups, i.e. P1, P2, and P0 (as control). To begin with, the sheep were divided into three cages where each cage entailed six sheep. In treatment 1, the samples were subjected to the injection of LPS B. abortus with Montanide ISA 70 Adjuvant with a dose of $50 \mu \mathrm{l} / \mathrm{ml}$ subcutaneously. On the other hand, in treatment 2 (Sari et al., 2014), the samples were injected with LPS $B$. abortus in Montanide ISA 70 adjuvant as much as $100 \mu \mathrm{l} / \mathrm{ml}$ subcutaneously. The sheep in the control group received no treatment. It should be noted that the sheep were kept in wooden stage cages. Feeding and drinking followed the norms of "Preferences for sheep or goats in Indonesia" (Budisatria et al., 2010).

\section{Sampling technique}

Sampling was carried out in two turns; the first turn was performed on August 29, 2016, and the second turn was run on September 12, 2016. A total of 18 samples were selected for blood sampling by taking blood from the jugular vein using a $3-5 \mathrm{ml}$ syringe.

\section{Serum separation}

To procure the blood serum, the collected blood was either put into a tube and centrifuged at a speed of $3000 \mathrm{rpm}$ for 20 minutes or was left aside so that the blood serum became separated and came to the surface of the tube. 


\section{Antibody titer examination with indirect ELISA technique}

The present study aimed to find out whether there was an antibody formed by the LPS B. abortus vaccine employing a serological test using the Indirect-ELISA test technique. The principle of the Indirect-ELISA test was antigen + antibody + antibody labeled enzyme. The Indirect-ELISA involved placing $100 \mu 1$ of LPS antigen from $B$. abortus weighing $1.25 \mu \mathrm{g} / \mathrm{ml}$ into a microplate and incubating at $37^{\circ} \mathrm{C}$ for 18 hours. Each plate hole was washed three times with a washing buffer of $200 \mu \mathrm{l}$ per plate. In the next step, $200 \mu \mathrm{l}$ of $4 \%$ buffer blocking was added to each plate hole, and then incubated at $37^{\circ} \mathrm{C}$ for 1 hour, washed again by placing the washing buffer of $200 \mu 1$ into each plate three times. To each standard antibody, the antibodies were added (1: 100 diluted), and $100 \mu$ was placed into the microplate hole and incubated at $37^{\circ} \mathrm{C}$ for 2 hours followed by the addition of $100 \mu$ anti-sheep antibodies labeled with the Alkaline Phosphatase enzyme in each plate hole, and incubated at $37^{\circ} \mathrm{C}$ for 1 hour. In the next step, the p-PNP substrate was added and incubated in a dark place at room temperature for 15-30 minutes, then $50 \mu \mathrm{l}$ of $\mathrm{NaOH} 3 \mathrm{n}$ stopper solution was added and a microplate reading was performed on the ELISA reader with a wavelength of $405 \mathrm{~nm}$ (Pangestika and Ernawati, 2018).

\section{IFN- $\gamma$ level examination with direct sandwich-ELISA}

In the current study, a serological test was employed using the Direct Sandwich-ELISA technique in order to find out the presence of IFN- $\gamma$ expression caused by LPS B. abortus (Prescott et al., 2002). The examination was carried out using the ELISA kit (Legend maxTM). With regard to the principle of the Direct Sandwich-ELISA Test, the first specific antibody was placed in the solid phase, then the added antigen was examined, and followed by the addition of the second antibody labeled as the enzyme. The Direct Sandwich-ELISA Test prepared a 96 well microplate that has been plotted with a monoclonal antibody against IFN- $\gamma$. Then, it was washed with a $400 \mu 1$ washing buffer twice. After that, $100 \mu 1$ of IFN- $\gamma$ standard solution was added to each plate hole, so that the concentration of each was $1000 \mathrm{pg} / \mathrm{ml}, 500 \mathrm{pg} / \mathrm{ml}, 250$ $\mathrm{pg} / \mathrm{ml}, 125 \mathrm{pg} / \mathrm{ml}, 62.5 \mathrm{pg} / \mathrm{ml}, 31.3 \mathrm{pg} / \mathrm{ml}, 156 \mathrm{pg} / \mathrm{ml}$, and $7.8 \mathrm{pg} / \mathrm{ml}$. Similarly, each plate hole was filled with $50 \mu 1 \mathrm{of}$ standard serum, and $50 \mu \mathrm{l}$ of Biotin-Conjugate were put in microwell and incubated for 2 hours at a temperature of 18$25^{\circ} \mathrm{C}$. After washing the microwell with washing buffer and drying it, $100 \mu \mathrm{l}$ of Sterptividin-HRP was added to all microwells and incubated for an hour at a temperature of $18-25^{\circ} \mathrm{C}$. Again after washing with washing buffer three times and adding $100 \mu \mathrm{l}$ of $\mathrm{TMB}$ substrate $\left(3,3^{\prime}, 5,5^{\prime}\right.$-Tetramethylbenzidine) to all plate holes, they were incubated at a temperature of $18-25^{\circ} \mathrm{C}$ for 10 minutes. Then, a $100 \mu \mathrm{l}$ of stopper solution was added to each plate hole, and the performance was read by ELISA reader with a wavelength of $450 \mathrm{~nm}$.

\section{Data analysis}

Data of antibody titer and IFN- $\gamma$ level were statistically analyzed using the Analysis of Variance (ANOVA) test. Pvalue less than 0.05 ( $\mathrm{p}<0.05)$ was considered statistically significant. Honest Significant Difference test (Tukey) was run using SPSS software, ver.21 (Statistical Product and Service Solution, 21).

\section{RESULTS}

\section{Examination and analysis of antibody titer data of the sheep by indirect ELISA test}

As mentioned earlier, the obtained data related to the sheep's antibody titer were statistically analyzed using ANOVA. In case of any significant difference $(\mathrm{P}<0.05)$, the Honest Significant Difference (Tukey) test was employed using SPSS software, version 21. Based on the result of the examination using the indirect ELISA technique, the data of antibody titer were listed in Table 1, while the difference in antibody titer in the second-week post-vaccination and the fourth-week post-vaccination could be seen in Figure 1.

The result of the ANOVA test showed that there were significant differences in each treatment $(\mathrm{p}<0.05)$. Therefore, data was analyzed again using the Honestly Significant Difference test (HSD test). Based on $p$-value ( $p<$ $0.05)$, the treatment group $\mathrm{P} 0$ (nothing is given) was significantly different from the P1 treatment group (50 $\mu \mathrm{g} / \mathrm{ml}$ given) and P2 $(100 \mu \mathrm{g} / \mathrm{ml}$ given), but there was no significant variance between P1 treatment group (50 $\mu \mathrm{g} / \mathrm{ml})$ and P2 treatment group $(100 \mu \mathrm{g} / \mathrm{ml})$. The comparison test between the antibody titer in the second-week post-vaccination and the antibody titer in the fourth-week post-vaccination showed no substantial difference $(p=0.304)$.

The average antibody titer in the P0 group in the second and fourth weeks neither increased nor decreased. However, the average antibody titer was increased in the P1 treatment group (50 $\mu \mathrm{g} / \mathrm{ml})$ and P2 $(100 \mu \mathrm{g} / \mathrm{ml})$ in the fourth week, compared to the antibody titer in the second week.

\section{Examination and analysis of IFN- $\gamma$ level data with ELISA direct sandwich test}

The obtained data on the IFN- $\gamma$ level of sheep were analyzed statistically using ANOVA. P value less than 0.05 was considered statistically significant. Honestly Significant Difference test was also employed using SPSS software, version 21. The examination of the Interferon-gamma level was aimed to find out the role of IFN- $\gamma$ in inducing the 
cellular immune system. Based on the results of the ELISA reader, the data listed in Table 2 were obtained, while the post-vaccination differences in the second week and the fourth week could be seen in Figure 2.

The average level of the IFN- $\gamma$ was determined in each treatment group, and it showed a significant difference among treatments $(\mathrm{p}<0.05)$. There was a noteworthy difference among treatment groups followed by the HST test as a multiple comparison test. The comparison test between P0 and P1 showed a significant difference $(p=0.034)$. In addition, there was a substantial difference in the comparison test between P0 and P2 (p = 0.005). However, the comparison test of P1 with P2 did not reveal any significant difference $(\mathrm{p}=0.716)$. The comparison between IFN- $\gamma$ level in the second-week post-vaccination and IFN- $\gamma$ level in the fourth-week post-vaccination was not prominently different $(\mathrm{p}=0.220)$.

The average of IFN- $\gamma$ level in the control group (P0) in the second and the fourth weeks post-vaccination showed a stable trend. In the P1 $(50 \mu \mathrm{g} / \mathrm{ml})$ and P2 $(100 \mu \mathrm{g} / \mathrm{ml})$ groups, the sampling of IFN- $\gamma$ level in the fourth-week postvaccination experienced a decrease, compared to the sampling of IFN- $\gamma$ level in the second-week post-vaccination.

Table 1. Average and standard deviation of sheep antibody titer for the not-given-treatment group (P0) and the given-treatment groups $(\mathrm{P} 1, \mathrm{P} 2)$ in the second and fourth weeks of post-vaccination.

\begin{tabular}{lcc}
\hline \multirow{2}{*}{ Treatments } & \multicolumn{2}{c}{ Antibody Titer $(\mathbf{X} \pm$ SD $)$} \\
\cline { 2 - 3 } $\mathbf{2}^{\text {nd }}$ Week & $\mathbf{4}^{\text {th }}$ Week \\
\hline P0 & $0,000^{\mathrm{a}} \pm 0,000^{*}$ & $0,000^{\mathrm{a}} \pm 0,000^{*}$ \\
P1 & $0,350^{\mathrm{b}} \pm 0,437^{*}$ & $0,883^{\mathrm{b}} \pm 1,183^{*}$ \\
P2 & $0,800^{\mathrm{b}} \pm 1,232^{*}$ & $0,966^{\mathrm{b}} \pm 1,148^{*}$ \\
Average & $0,383^{\mathrm{a}} \pm 0,785^{* *}$ & $0,616^{\mathrm{a}} \pm 1,001^{* *}$ \\
\hline
\end{tabular}

* different superscripts in the same column, showing significant differences $(\mathrm{p}<0.05$ ); $* *$ different superscripts on the same row, showing significant differences. P0: The control group which received no treatment entailed six sheep aged two years, P1: The group involved six sheep aged two years treated by giving B. abortus LPS injection in Montanide ISA 70 adjuvant at a dose of $50 \mu \mathrm{g} / \mathrm{ml}$ subcutaneously, P2: The group included six sheep aged two years treated by giving B. abortus LPS injection in Montanide ISA 70 adjuvant at a dose of 100 $\mu \mathrm{g} / \mathrm{ml}$ subcutaneously.

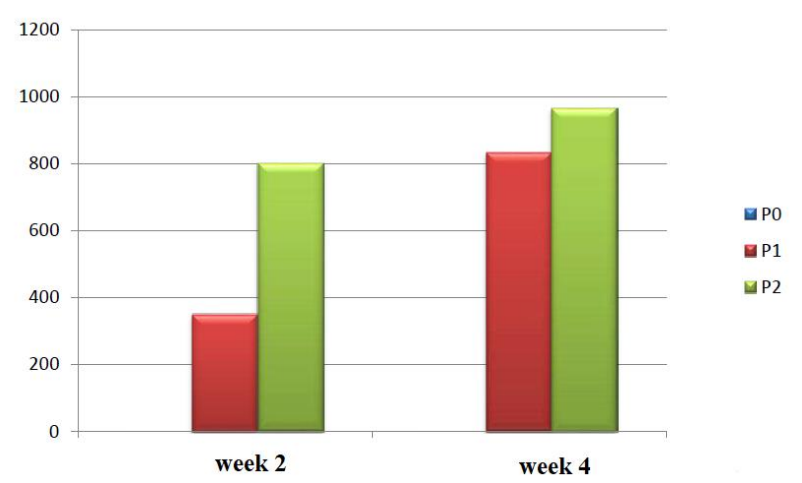

Figure 1. Average graph of sheep antibody titer for a notgiven-treatment group (P0) and given-treatment groups $(\mathrm{P} 1, \mathrm{P} 2)$ at the second and fourth weeks of postvaccination
Table 2. Average and standard deviation of IFN- $\gamma$ level of sheep of a not-given-treatment group (P0) and giventreatment groups $(\mathrm{P} 1, \mathrm{P} 2)$ in the second and fourth weeks of post-vaccination.

\begin{tabular}{lcc}
\hline \multirow{2}{*}{ Treatments } & \multicolumn{2}{c}{ Titer antibody $(\mathbf{X} \pm$ SD) } \\
\cline { 2 - 3 } & $\mathbf{2}^{\text {nd }}$ Week & $\mathbf{4}^{\text {th }}$ Week \\
\hline P0 & $5.267^{\mathrm{a}} \pm 0.911^{*}$ & $5.392^{\mathrm{a}} \pm 0.094^{*}$ \\
P1 & $4.998^{\mathrm{b}} \pm 0.776^{*}$ & $4.468^{\mathrm{b}} \pm 0.313^{*}$ \\
P2 & $4.701^{\mathrm{b}} \pm 0.490^{*}$ & $4.410^{\mathrm{b}} \pm 0.257^{*}$ \\
Average & $4.988 \pm 0.741^{* *}$ & $4.872 \pm 0.639^{* *}$ \\
\hline
\end{tabular}

* different superscripts in the same column, showing significant differences $(\mathrm{p}<0.05)$; $* *$ different superscripts on the same row, showing significant differences $(\mathrm{p}<0.05)$; P0: The control group which received no treatment entailed six sheep aged two years, P1: The group involved six sheep aged two years treated by giving B. abortus LPS injection in Montanide ISA 70 adjuvant at a dose of $50 \mu \mathrm{g} / \mathrm{ml}$ subcutaneously, P2: The group included six sheep aged two years treated by giving $\mathrm{B}$. abortus LPS injection in Montanide ISA 70 adjuvant at a dose of $100 \mu \mathrm{g} / \mathrm{ml}$ subcutaneously.

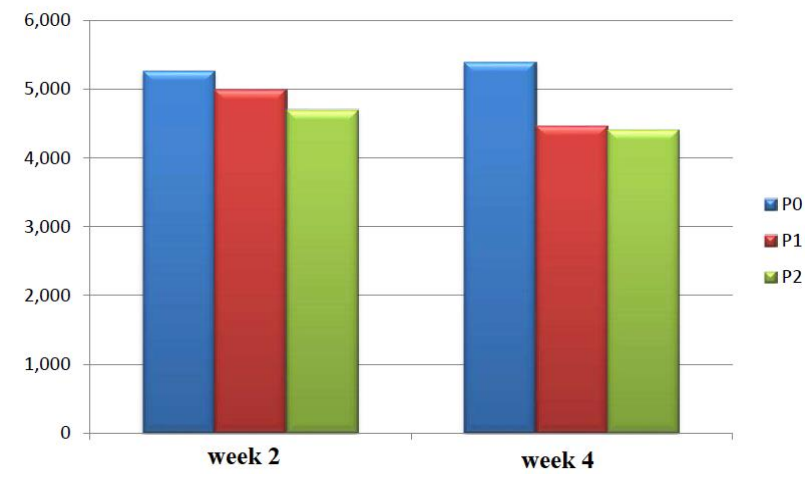

Figure 2. Average graph of IFN- $\gamma$ level of sheep of the not-given-treatment group (P0) and given-treatment groups $(\mathrm{P} 1, \mathrm{P} 2)$ in the second and fourth weeks of postvaccination

\section{DISCUSSION}

The administration of $B$. abortus lipopolysaccharide subunit in the Montanide ISA 70 adjuvant at doses of $50 \mu \mathrm{g} / \mathrm{ml}$ and $100 \mu \mathrm{g} / \mathrm{ml}$ in the post-vaccination sampling at the second week showed an increase in titer values of 0.350 and 0.833 , respectively, compared to the control group's titer. Animal antibodies provided by B. abortus vaccine were detected in the second-week post-vaccination, and it peaked in the sixth-week post-vaccination (Sudibyo, 1995). After the sixth week, the formed antibodies started to decrease. Other studies stated that no antibody responses during the fourth week after the inoculation, and there was only a sharp increase at the sixth week after the inoculation (Praja et al., 2017). The intensity of the humoral immune response could be demonstrated by the serum antibody level (Pooley et al., 2019). 
When animals or humans are exposed to an antigen, a premier immune response characterized by the appearance of IgM occurs a few days after the exposure, leading to an increase in the serum antibody level. The IgM level peaks on the seventh day (Sathe and Cusick, 2021). After the sixth and seventh days, IgG is detected in the serum, whereas IgM begins to decrease before IgG level peaked 10-14 days after the exposure (Pajuaba et al., 2010) The antibody level continues to decrease, and only is slightly detected after four to five weeks.

The administration of $B$. abortus lipopolysaccharide subunit in Montanide ISA 70 adjuvant at the doses of 50 $\mu \mathrm{g} / \mathrm{ml}$ and $100 \mu \mathrm{g} / \mathrm{ml}$ in post-vaccination sampling at the second week showed a reduction in IFN- $\gamma$ level of 4.998 and 4.701, respectively, compared to 5.267 value of IFN- $\gamma$ for the control group. Moreover, IFN- $\gamma$ level value of animals that did not receive any treatment showed lower values than those animals that received treatments (Segura et al., 2007). Many factors that affected the antibody response were produced in vivo, including the composition of conjugation, carrier protein, immunization route, adjuvant, animal species, and detection method (Davar et al., 2015). At high doses, interferon could reduce cellular and humoral immune responses. At low doses, interferon-stimulated the immune system by increasing the activity of Natural Killing cells (NK cells), macrophage, T cells, and by regulating antibody production (Baratawidjaja, 2006). Regarding time, the value of IFN- $\gamma$ level in the sampling of the second-week post-vaccination was higher than the value of IFN- $\gamma$ level in the sampling of the fourth-week post-vaccination. The result showed that IFN- $\gamma$ level reached the optimal level in the second-week post-vaccination. Based on the statistical test, the obtained result was indicative of 0.220 ( $\mathrm{P}>0.05$ ). Consequently, it could be inferred that the time factor did not have any significant effect on the IFN- $\gamma$ level of the sheep which received the Brucella abortus lipopolysaccharide subunit vaccine.

Davar et al. (2015) mentioned that IFN- $\gamma$ level peaked seven days after the vaccination, the IFN- $\gamma$ level continued to decrease after seven days, and very little IFN- $\gamma$ was detected 180 days after the vaccination. The IFN- $\gamma$ was a major cytokine for macrophage activating cytokine, and played a major role in the non-specific and cellular-specific immunity. IFN- $\gamma$ is believed to be a cytokine that activated macrophages to kill phagocytes. IFN- $\gamma$ stimulates the expression of the Major Histocompatibility Complex (MHC-I), Major Histocompatibility Complex Class 2 (MHC-II), and AntigenPresenting Cells (APC) costimulator. IFN- $\gamma$ increases CD4 cell differentiation to the Thiamine biosynthetic bifunctional enzyme (Th1) subcells, and prevents Th2 cell proliferation. IFN- $\gamma$ acts against B cells in the transfer of IgG subclasses that bound Fc $\gamma-\mathrm{R}$ to phagocytes. and activates the complement. Both of these processes increase phagocytosis of the microbes operationalized (Baratawidjaja, 2006).

The adaptive or specific immune response was slower, because it needed antigen sensitivity, but has better protection against the same antigen. This immune system was run by B lymphocytes and $\mathrm{T}$ lymphocytes derived from lymphoid progenitor cells. T lymphocyte cells were responsible for the production of cytokines and cytotoxicity (cellular immunity), and B lymphocytes produced antibodies (humoral immunity; Skendros and Boura, 2013). The IFN- $\gamma$ could divert Ig that participated in the microbial elimination. IFN- $\gamma$ activated neutrophils and stimulated the cytolytic effect of NK cells (Baratawidjaja, 2006).

Adjuvant has an important role in the success of vaccination helping to form antibody responses. The use of adjuvant should be adapted to several criteria, namely target species, antigen, type of immune response, inoculation route, and immunity duration (Aucouturier et al., 2001). Montanide was a water-in-oil adjuvant consisting of oil and a very fine emulgator from the mannide monooleate group. Formulation using Montanide adjuvant-induced a long-term and strong immunity. Compared to the traditional oil emulsion, Montanide was more stable and easier to be injected. In addition, Montanide also has a higher immunopotentiation and fewer side effects (Tehrani et al., 2014). The addition of an adjuvant to the vaccine could increase the immunogenicity of the vaccine. Adjuvant was an ingredient mixed into a vaccine to enhance the immune response, both humoral and cellular immunity (Murphy et al., 1999).

\section{CONCLUSION}

The administration of $B$. abortus lipopolysaccharide subunit in the Montanide ISA 70 adjuvant can influence the formation of antibodies and IFN- $\gamma$ secretion on the sheep. The difference in dose given during the vaccination influenced the formation of antibodies and IFN- $\gamma$ secretion. Administration of $100 \mu \mathrm{g} / \mathrm{ml}$ produced antibody titer value greater than the dose of $50 \mu \mathrm{g} / \mathrm{ml}$ and injecting the dose of $50 \mu \mathrm{g} / \mathrm{ml}$ produced an IFN- $\gamma$ level greater than the dose of $100 \mu \mathrm{g} / \mathrm{ml}$. There were significant differences regarding antibody titer and IFN- $\gamma$ level in the second-and fourth-week postvaccination.

\section{DECLARATION}

\section{Author's contribution}

All authors have similar roles in conducting, writing, and editing the manuscript.

\section{Conflict of Interests}

The authors have not declared any conflict of interest in this work. 


\section{REFERENCES}

Aucouturier J, Dupuis L, and Ganne V (2001). Adjuvants designed for veterinary and human vaccines. Vaccine, 19: 2666-2672. DOI: https://www.doi.org/10.1016/s0264-410x(00)00498-9

Baratawidjaja K (2006). Imunologi Dasar Yogyakarta: Balai Penerbit Fakultas Kedokteran Universitas Airlangga, Ailangaa, pp. 3047. Available at: http://lib.ui.ac.id/detail?id=20417471

Budisatria I, Udo H, Eilers C, Baliarti E, and Zijpp A (2010). Preferences for sheep or goats in Indonesia. Small Ruminant Research, 88: 16-22. DOI: https://www.doi.org/10.1016/J.SMALLRUMRES.2009.11.002

Davar S, Vaziri F, and Eftekhary M (2015). Preparation and evaluation of a new lipopolysaccharide-based conjugate as a vaccine candidate for brucellosis. Osong Public Health and Research Perspectives, 6(1): 9-13. DOI: http://www.dx.doi.org/10.1016/j.phrp.2014.10.012

Davis DS, and Elzer PH (2002). Brucella vaccines in wildlife. Veterinary Microbiology, 90: 533-544. DOI: https://www.doi.org/10.1016/s0378-1135(02)00233-x

Murphy F, Gibbs E, Horzinek M, and Michael S (1999). Veterinary virology third edition. Elsevier Academic Press, United States of America. pp. 170-181. Available at: https://www.elsevier.com/books/veterinary-virology/murphy/978-0-12-511340-3

Pajuaba AC, Silva DA, and Mineo JR (2010). Evaluation of indirect enzyme-linked immunosorbent assays and IgG avidity assays using a protein A-peroxidase conjugate for the serological distinction between Brucella abortus S19-vaccinated and -infected cows. Clinical and Vaccine Immunology, 17(4): 588-595. DOI: https://www.doi.org/10.1128/CVI.00444-09

Pangestika R, and Ernawati R (2018). Antiviral activity effect of silver nanoparticles (agnps) solution against the growth of infectious bursal disease virus on embryonated chicken eggs with Elisa Test. KnE Life Sciences, 3(6): 536-548. DOI: http://www.dx.doi.org/10.18502/kls.v3i6.1181

Pooley HB, Begg DJ, Plain KM, Whittington RJ, Purdie AC, and de Silva K (2019). The humoral immune response is essential for successful vaccine protection against paratuberculosis in sheep. BMC Veterinary Research, 15(1): Article number 223. DOI: https://www.doi.org/10.1186/s12917-019-1972-z

Praja RN, Handijatno D, Koesdarto S, Yudhana A, Mikrobiologi D, and Helmintologi L (2017). Characterization of virb4 protein from local isolate of Brucella abortus using sodium dodecyl sulfate polyacrylamide gel electrophoresis technique. Jurnal Kedokteran Hewan, 18(36): 416-421. DOI: https://www.doi.org/10.21157/j.ked.hewan.v12i1.8091

Prescott JF, Menzies PI, and Hwang YT (2002). An interferon-gamma assay for diagnosis of Corynebacterium pseudotuberculosis infection in adult sheep from a research flock. Veterinary Microbiology, 88(3): 287-297. DOI: https://www.doi.org/10.1016/s0378-1135(02)00121-9

Rantam FA (2003). Metode imunologi. Surabaya: Airlangga University Press, Airlangaa.

Ratnasari R, Handijatno D, Suwarno, and Rantam FA (2018). Antigenic derterminants omp2a gene of B. abortus local isolate. Acta Veterinaria Indonesia, 2(1): 17-25. Available at: https://journal.ipb.ac.id/index.php/actavetindones/article/download/8784/6858/

Sari RR, Oktorina R, Rofiqul A, and Yuniarti LS (2014). Validasi metode uji mikroskopis dan real time polymerase chain reaction pada bahan baku pakan ternak. pros konf ilm vet nas ke-13, Palembang, Indonesia. (23-26 November 2014). Prosiding Konferensi Ilmiah Veteriner Nasional, 13: 23-26. Available http://journal.ipb.ac.id/index.php/hemera/article/download/18650/13157

Sathe A, and Cusick JK (2021). Biochemistry, Immunoglobulin M. StatPearls Publishing. Available at: https://www.ncbi.nlm.nih.gov/books/NBK555995/

Segura S, Gamazo C, Irache JM, and Espuelas S (2007). Gamma interferon loaded onto albumin nanoparticles : In vitro and in vivo activities against Brucella abortus. Antimicrobial Agents and Chemotherapy, 51(4): 1310-1314. DOI: https://www.doi.org/10.1128/AAC.00890-06

Skendros P, and Boura P (2013). Immunity to brucellosis. Revue Scientifique Et Technique, 32(1): 137-147. DOI: https://www.doi.org/10.20506/rst.32.1.2190

Sudibyo A (1995). The difference of serological responses between naturally infected, experimentally infected, and vaccinated cattle with Brucella abortus strain 19 vaccine. Jurnal Ilmu Ternak dan Veteriner, 1(2): 117-122. DOI: http://www.dx.doi.org/10.14334/jitv.v1i2.21

Tehrani NK, Mahdavi M, Imani Fooladi AA, and Tabatabaie F (2014). Survey protein vaccine formulated with montanide ISA 70 effects following immunization and after challenge with Leishmania major. Biosciences Biotechnology Research Asia, 11(1): 5360. Available at: http://www.biotech-asia.org/vol11no1/survey-protein-vaccine-formulated-with-montanide-isa-70-effectsfollowing-immunization-and-after-challenge-with-leishmania-major/

Xavier NM, Den Hartigh A, Santos LR, Paixao AT, and Tsolis MR (2014). Pathogenesis of Brucella spp. The Open Veterinary Science Journal, 4(1): 109-118. DOI: http://www.dx.doi.org/10.2174/1874318801004010109 